\title{
Isoform-Specific Early Trafficking of AMPA Receptor Flip and Flop Variants
}

\author{
Sarah K. Coleman, ${ }^{1}$ Tommi Möykkynen, ${ }^{2}$ Chunlin Cai, ${ }^{1}$ Lotta von Ossowski, ${ }^{1}$ Esa Kuismanen, ${ }^{1}$ Esa R. Korpi, ${ }^{2}$ and \\ Kari Keinänen ${ }^{1}$ \\ ${ }^{1}$ Department of Biological and Environmental Sciences, Division of Biochemistry, Viikki Biocenter, and 2Institute of Biomedicine, Pharmacology, \\ Biomedicum Helsinki, University of Helsinki, FIN-00014 Helsinki, Finland
}

Flip and flop splice variants of AMPA receptor subunits are expressed in distinct but partly overlapping patterns and impart different desensitization kinetics to cognate receptor channels. In the absence of specific antibodies, isoform-specific differences in trafficking or localization of native flip and flop subunits remain uncharacterized. We report that in several transfected cell lines, transport of homomeric glutamate receptor $(\mathrm{GluR})-\mathrm{D}_{\text {flop }}$ receptors is largely blocked at the endoplasmic reticulum (ER) exit, whereas GluR-D $\mathrm{D}_{\text {flip }}$ undergoes complex glycosylation and reaches the plasma membrane at $>10 \times$ higher levels than GluR- $\mathrm{D}_{\text {flop }}$, as determined by immunofluorescence, patch-clamp recordings and biochemical assays. The transport difference between flip and flop is independent of activity, is primarily determined by amino acid residue 780 (Leu in flop, Val in flip), and is manifested even in the secretion of the soluble ligandbinding domain, suggesting it is independent of oligomerization. Coexpression with stargazin or with the flip isoform rescues the surface expression of GluR- $\mathrm{D}_{\text {flop }}$ near to the level exhibited by GluR- $\mathrm{D}_{\text {flip }}$. Our results demonstrate that the extracellular flip/flop region, via interactions with ER luminal splice form-specific protein(s), plays a hitherto unappreciated and important role in AMPA-receptor trafficking.

Key words: AMPA receptor; ER exit; flip/flop splice variants; GluR-D; GluR4; trafficking

\section{Introduction}

AMPA receptors are assembled from a set of four subunits, glutamate receptors (GluRs) A to D (or GluR1-GluR4) in a homomeric and heteromeric manner (for review, see Mayer, 2005; Palmer et al., 2005). Further subunit variants are generated by alternative splicing (Sommer et al., 1990; Gallo et al., 1992; Köhler et al., 1994) and by RNA editing (Sommer et al., 1991; Lomeli et al., 1994). Subunit-specific receptor trafficking is studied intensively because the number and subunit composition of AMPA receptors have emerged as key determinants of synaptic strength (Malinow and Malenka, 2002; Collingridge et al., 2004). The cytoplasmic carboxy-terminal tail, subject to alternative splicing in some subunits, plays an important role in trafficking. Certain forms of long-term potentiation in hippocampal pyramidal cells are characterized by selective synaptic insertion of AMPA receptors with long-tailed subunits, GluR-A, GluR-B LONG $_{\text {or }}$

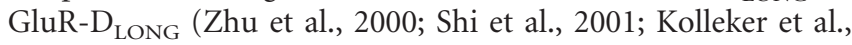
2003). In contrast, AMPA receptors composed of short-tailed subunits are under a constant turnover (Passafaro et al., 2001; Shi et al., 2001). A number of proteins interacting with the cytoplas-

Received May 31, 2006; revised Sept. 18, 2006; accepted Sept. 18, 2006.

This work was supported by Academy of Finland Grant 202892. We thank Danielle Bansfield for technical assistance. We thank Hong Li and Dr. Claudio Rivera (Institute of Biotechnology, University of Helsinki) for help in neuronal culture.

Correspondence should be addressed to Kari Keinänen, Department of Biological and Environmental Sciences, Division of Biochemistry, Fl-00014 University of Helsinki, Finland. E-mail: kari.keinanen@helsinki.fi.

DOI:10.1523/JNEUROSCI.2301-06.2006

Copyright $\odot 2006$ Society for Neuroscience $\quad 0270-6474 / 06 / 2611220-10 \$ 15.00 / 0$ mic tails of AMPA receptor subunits in a subunit or splice formspecific manner have been identified and characterized (for review, see Malinow and Malenka, 2002; Bredt and Nicoll, 2003; Sheng and Hyoung Lee, 2003; Collingridge et al., 2004).

Less attention has been focused on the role of alternative splicing of the flip/flop exon in AMPA-receptor trafficking. The flip and flop isoforms differ at 9 to 10 positions in the extracellular ligand-binding domain (Sommer et al., 1990). They display distinct but partially overlapping temporal and spatial expression patterns in the nervous system (Sommer et al., 1990; Monyer et al., 1991). Generally, flop variants desensitize faster, although the kinetic difference depends on the subunit and, for heteromeric channels, on subunit compositions (Sommer et al., 1990; Mosbacher et al., 1994; Koike et al., 2000; Grosskreutz et al., 2003). Key determinants responsible for the differences between the isoforms map to helix J, predicted to form a dimer interface in the active conformation of the receptor (Partin et al., 1995; Sun et al., 2002; Quirk et al., 2004).

In the present report, we show that the flip/flop splicing has an unprecedentedly strong effect on the maturation and cellular trafficking of AMPA receptors in several cell lines: homomeric GluR- $D_{\text {flop }}\left(-\mathrm{D}_{\mathrm{o}}\right)$ receptors accumulate in the endoplasmic reticulum (ER) whereas the corresponding $-\mathrm{D}_{\text {flip }}\left(-\mathrm{D}_{\mathrm{i}}\right)$ receptors are efficiently transported to cell surface. Different transport competence of the isoforms is independent of desensitization and receptor activity, is manifested also in secretion of the soluble ligandbinding domain, and is determined by the residue 780 outside helix J. The transport block of the flop isoform is reversible and 
surface expression of GluR- $\mathrm{D}_{\mathrm{o}}$ is completely rescued by coexpression with stargazin (Chen et al., 2000). Our results suggest an interaction between the extracellular flip/flop region and isoform-specific ER luminal proteins as a novel step in the early trafficking of AMPA receptors.

\section{Materials and Methods}

DNA constructs. Expression plasmids encoding N-terminally flag- or myc-tagged rat AMPA receptor subunits were constructed in pcDNA3.1 (Stratagene, La Jolla, CA) as described previously for GluR- $\mathrm{D}_{\mathrm{i}}$ (Coleman et al., 2003). GluR-D mutants were created by PCR methodology and engineered in GluR-D that lacked the N-terminal domain (residues 22402 "GluR-D $\Delta X$ ") (Pasternack et al., 2002), then transferred to fulllength molecule if required. GluR-D S1S2 fusion protein cDNAs encoding $\mathrm{N}$-terminal signal peptide and flag epitope and C-terminal myc tag were inserted into pEGFP-C1 (Clontech, Mountain View, CA), replacing the GFP sequence. All constructs were verified by restriction mapping and sequencing of PCR-amplified regions. The plasmid encoding rat NR1 cDNA in pRK5 vector was a kind gift from Drs. Peter Seeburg and Rolf Sprengel (Max Planck Institute for Medical Research, Heidelberg, Germany). The GluR-D short (GluR4c) cDNA plasmid was kindly donated by Dr. Andres Buonanno (National Institute of Child Health and Human Development-National Institutes of Health, Bethesda, MD). The plasmids encoding mouse and human stargazin were generous gifts from Drs. Verity Letts (The Jackson Laboratory, Bar Harbor, MN) and John L. Black III (Mayo Medical School, Rochester, MN), respectively.

Antibodies. Primary antibodies used in immunofluorescence staining were monoclonal M2 anti-flag ( $1 \mu \mathrm{g} / \mathrm{ml}$; Sigma, St. Louis, MO). Antibodies from AbCam (Cambridge, UK) were rabbit anti-myc $(2 \mu \mathrm{g} / \mathrm{ml})$; rabbit anti-COPII $(3 \mu \mathrm{g} / \mathrm{ml})$; rabbit anti-GFP sera (1:1000); monoclonal anti-p58K ascites fluid (1:50). Others antibodies used were rabbit antiNMDAR1 (2 $\mu \mathrm{g} / \mathrm{ml}$; Chemicon); monoclonal anti-BAP31 (1:2) (Määttä et al., 2000); rabbit anti-Stargazin sera (1:500). Secondary antibodies used were Cy3-conjugated anti-mouse $(7 \mu \mathrm{g} / \mathrm{ml})$; Cy2-conjugated antirabbit ( $15 \mu \mathrm{g} / \mathrm{ml})$; Rhodamine Red-X-conjugated anti-rabbit $(7 \mu \mathrm{g} / \mathrm{ml})$, all from Jackson ImmunoResearch (West Grove, PA) and Alexa Fluor 488 conjugated anti-mouse $(5 \mu \mathrm{g} / \mathrm{ml}$ ) from Invitrogen (Eugene, OR).

For immunoblotting, rabbit antisera anti-GluR-A $\mathrm{A}_{\text {CTD }}$ (1:2000) (Cai et

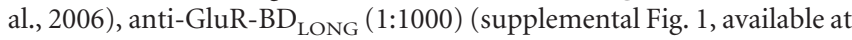
www.jneurosci.org as supplemental material) or anti-stargazin (1:5000), all made in-house, were used. Commercial antibodies were rabbit antiGluR2/3 (Chemicon; $0.2 \mu \mathrm{g} / \mathrm{ml}$ ) and rabbit anti-myc (AbCam; $0.1 \mu \mathrm{g} /$ $\mathrm{ml}$ ); anti-flag M2 mAb (Sigma; $0.5 \mu \mathrm{g} / \mathrm{ml}$ ); secondary antibodies were anti-mouse (1:1000) or anti-rabbit (1:8000) conjugated to horseradish peroxidase (Amersham Biosciences, Piscataway, NJ).

Cell culture and transfection. Human embryonic kidney 293 (HEK293) and Cos-7 cells were cultured and transfected as described previously (Coleman et al., 2003). For coexpression, cDNAs were transfected at a 1:1 ratio. For patch clamp experiments, the cells were cotransfected with pEGFP-C1 for visualization of GFP fluorescence. Primary cortical neurons were isolated from embryonic day 17 (E17) mouse embryos and transfected after $9 \mathrm{~d}$ in vitro (DIV) and analyzed at 14 DIV as described previously (Cai et al., 2006).

Electrophysiology. Whole-cell patch-clamp recordings were made from GFP-positive HEK293 cells with Axopatch 200B amplifier and Clampex 8.2 software (Molecular Devices, Sunnyvale, CA) (Möykkynen et al., 2003). Electrodes were pulled from borosilicate glass capillaries (World Precision Instruments, Stevenage, UK) and had a resistance of 4-6 M $\Omega$ when filled with internal solution containing the following (in $\mathrm{mM}$ ): 100 $\mathrm{N}$-methyl-D-glucamine, $100 \mathrm{CH}_{3} \mathrm{SO}_{3} \mathrm{H}, 40 \mathrm{CsF}, 10 \mathrm{MgCl}_{2}, 10 \mathrm{HEPES}, 5$ EGTA, pH 7.4. The cells were continuously perfused with recording solution containing the following (in mM): $150 \mathrm{NaCl}, 2.5 \mathrm{KCl}, 2.5 \mathrm{CaCl}_{2}$, $1 \mathrm{MgCl}_{2}, 10$ HEPES, 10 glucose, $\mathrm{pH}$ 7.4. Glutamate was dissolved in the recording solution and the $\mathrm{pH}$ of the solution adjusted to 7.4. Glutamate was applied to the cells using a stepper motor driven applicator (Warner Instruments, Hamden, CT). Each glutamate application was done twice and traces were averaged. Prism 4.0 software (GraphPad, San Diego, CA) was used for the statistical analysis.
Immunofluorescence staining and quantification. Transfected Cos7 cells were fixed and immunostained as described for HEK293 cells in (Coleman et al., 2003). Neuronal staining was done as described previously (Cai et al., 2006). Images were obtained as described previously (Coleman et al., 2003; Cai et al., 2006).

An Olympus (Tokyo, Japan) Provis AX70 epifluorescence microscope coupled to a Photometrics (Tucson, AZ) SenSys air-cooled CCD camera was used. Quantification of images was done by pixel intensity analysis using Image ProPlus software. Images for analysis were taken under the same conditions within an experiment (antibodies; gain; exposure time) and as standard a $40 \times 0.75$ numerical aperture objective lens was used. Conditions were set such that the images were nonsaturating. No modification was done to analyzed images. A minimum of five fields of view were measured per construct per transfection; each construct was independently transfected at least three times. Values obtained were normalized to an internal standard for comparison between experiments. Statistical analysis, $t$ tests, or one-way ANOVA followed by Bonferroni was done in Prism 4.0.

Cell transport block. Cos-7 cells transfected for expression of the protein of interested were incubated at $15^{\circ} \mathrm{C}$ for $2 \mathrm{~h}$ to prevent exit from the ER (Kuismanen and Saraste, 1989). The cells were fixed and permeabilized as described and costained with appropriate antibodies to reveal the subcellular localization of the proteins. Images were taken as described above, except a $100 \times 1.3$ numerical aperture objective lens was used.

Cell surface biotinylation and immunoprecipitation. Transfected HEK293 cells were rinsed with PBS containing $1 \mathrm{~mm} \mathrm{CaCl}_{2}, 0.5 \mathrm{~mm} \mathrm{KCl}$, $2.5 \mathrm{~mm} \mathrm{MgCl}_{2}$, and incubated with EZ-Link sulfo-NHS-SS-Biotin (Pierce, Rockford, IL), $0.5 \mathrm{mg} / \mathrm{ml}$, in the above buffer for $30 \mathrm{~min}$ at room temperature. Nonreacted reagent was removed by washing cells with the above buffer. Triton X-100 extracts were made as described previously and subject to immunoprecipitation (Coleman et al., 2003) or bound to streptavidin-conjugated Sepharose (Amersham Biosciences). In both cases bound proteins were harvested and analyzed as described by Coleman et al. (2003).

Quantification of immunoblots. Immunoblots were scanned via Adobe (San Jose, CA) Photoshop. Digital images were quantified using Image ProPlus software, no modification was done to analyzed images. Band optical density was determined relative to background levels taken from immediately above or below the band of interest within the same lane. Each experiment was independently done a minimum of three times; two separate film exposures were examined for each experiment. Values obtained were normalized to an internal standard for comparison between experiments.

Endoglycosidase H treatment. Transfected cells were extracted as described previously. The proteins of interest were immunoprecipitated, then washed, resuspended in 5\% SDS, $10 \% \beta$-mercaptoethanol (50 $\mu \mathrm{l}$ ), and heated $95^{\circ} \mathrm{C}$ for $15 \mathrm{~min}$. Sodium citrate $(0.5 \mathrm{M} ; 5 \mu \mathrm{l})$ was added followed by endoglycosidase H (1000 U; $2 \mu \mathrm{l}$; New England Biolabs, Beverly, MA) according to manufacturers instructions. After $2 \mathrm{~h}$ incubation at $37^{\circ} \mathrm{C}$ samples were analyzed by SDS-PAGE and immunoblotting.

Antibody production. Antisera against glutathione S-transferase fusion protein of rat GluR-D (Swiss-Prot/TrEMBL P19493) C-terminal domain residues 835-902 and against His-tagged mouse stargazin (O88602) C-terminal residues 203-323 were generated in New Zealand White rabbits according to standard protocols (Harlow and Lane, 1988) in the Animal Facility of the Viikki Biocenter, University of Helsinki, Helsinki, Finland.

\section{Results \\ Different surface expression of flip and flop isoforms of GluR-A and -D}

Our initial studies revealed consistent differences in the surface expression of N-terminally flag-tagged GluR-A and GluR-D receptors in transfected cell lines, which on closer analysis turned out to be determined by the alternative spliced flip/flop cassette present in the constructs. As shown in Figure 1, the flip and flop isoforms of GluR-A and GluR-D were expressed at the same total 
A
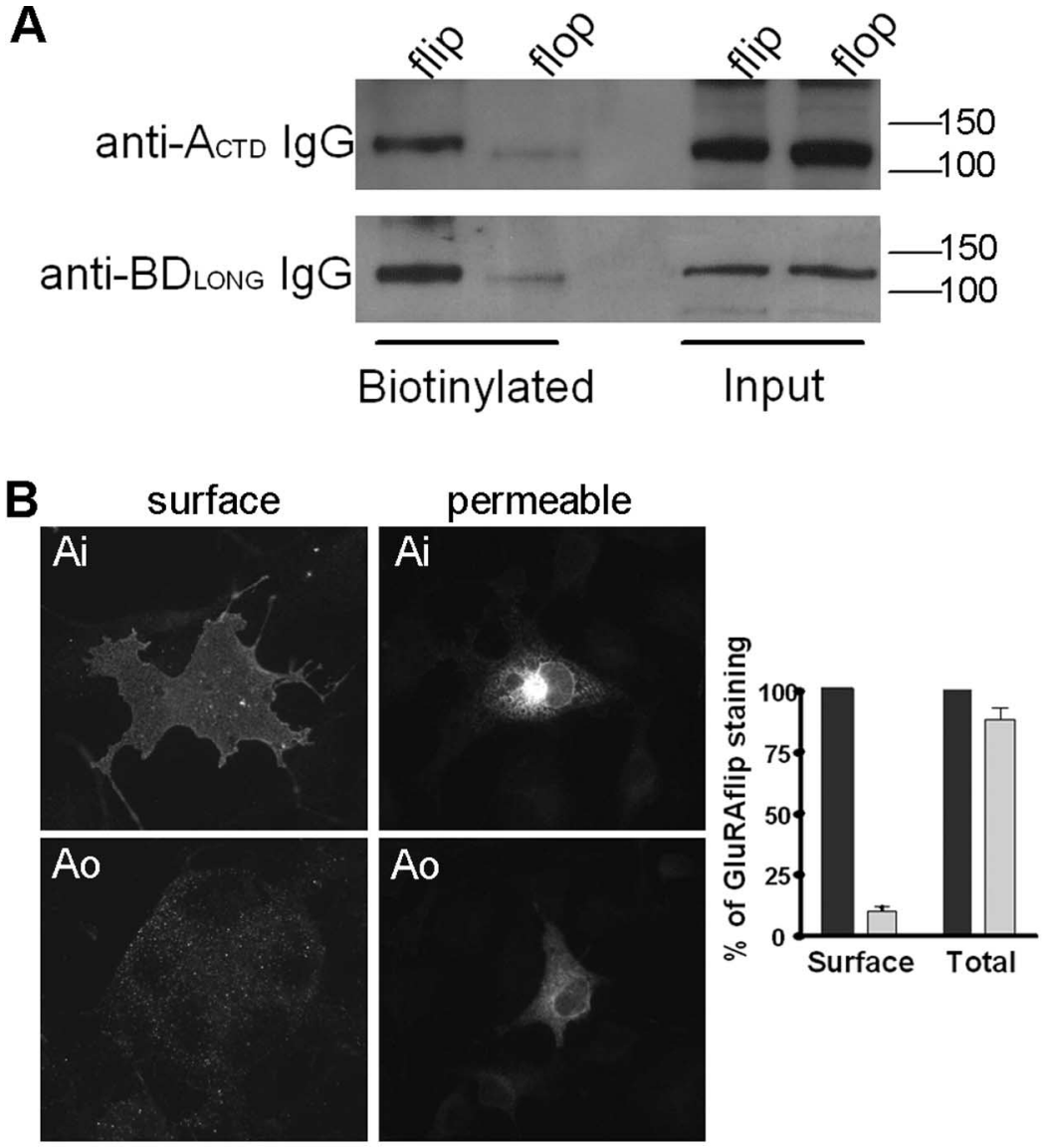

Aflip $\square$ Aflop
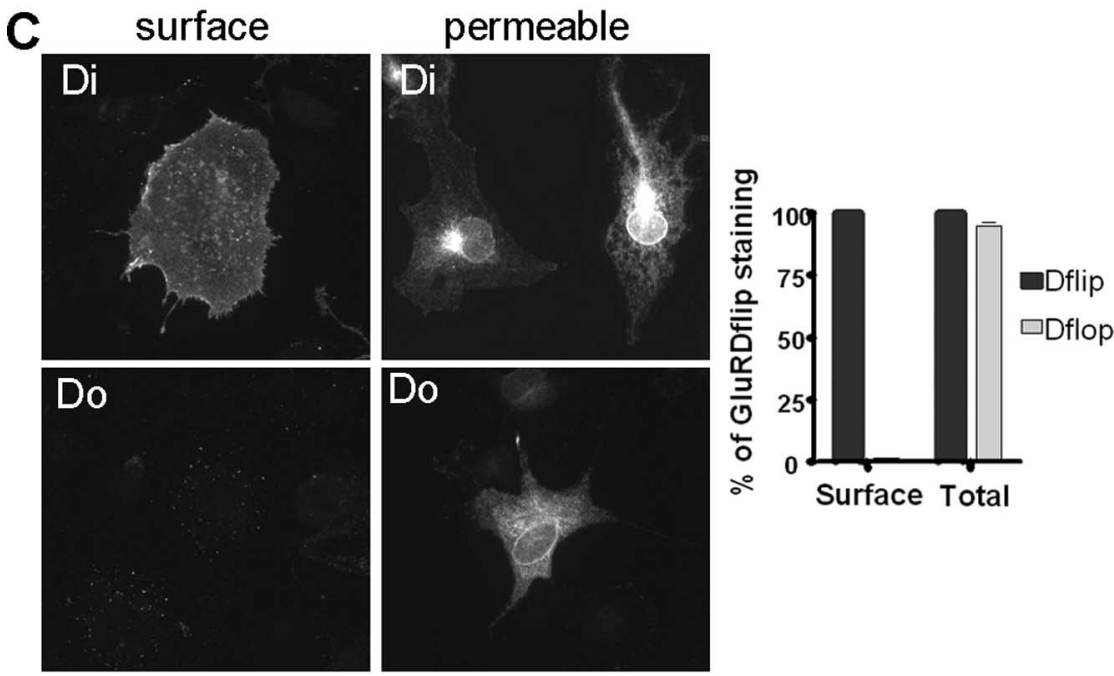

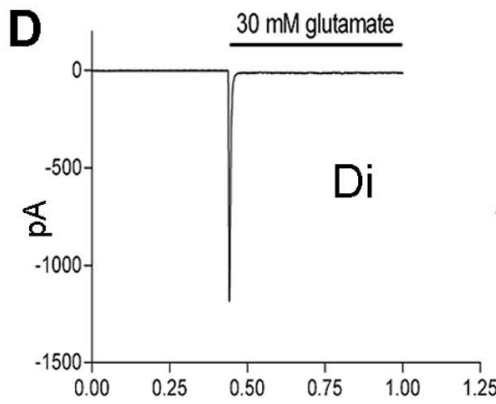

$t(s)$

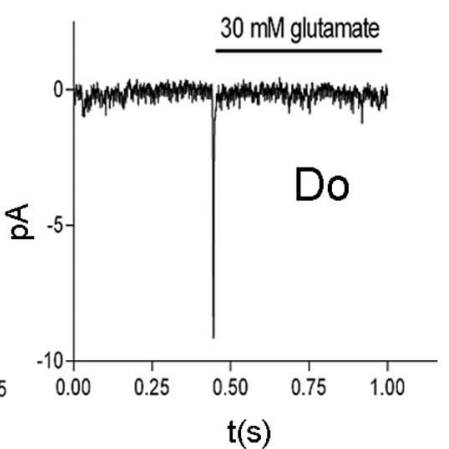

level in transfected HEK293 cells. In contrast, surface biotinylation and flag immunofluorescence of nonpermeabilized cells showed that for both subunit types, the flip isoform was strongly present on the plasma membrane, whereas the corresponding flop isoforms were barely seen on cell surface (Fig. 1). A similar relationship between the splice isoform and surface expression level was observed in three different cell lines, HEK293 (Fig. 1A), Cos7 (Fig. $1 B, C$ ), and HeLa cells (data not shown). Quantification of the nonpermeabilized immunostaining indicated that the difference was $\sim 10$-fold in GluR-A and $\sim 100$-fold for GluR-D (Fig. $1 B, C$, graphs). This was in agreement with the analyses of the respective surface biotinylation immunoblots (data not shown). The difference in the amount of receptor on cell surface was reflected by the number of active channels as shown by whole-cell patch-clamp recordings of glutamateinduced peak currents from HEK293 cells expressing homomeric GluR- $\mathrm{D}_{\mathrm{i}}(1310 \pm$ $612 \mathrm{pA} ; n=5)$ or $-\mathrm{D}_{\mathrm{o}}$ receptors $(19 \pm 18$ pA; $n=5$ ) (Figs. $1 D, 5 D$ ).

\section{Receptor localization is not affected by functional activity}

The flip/flop cassette is part of the ligandbinding domain and known to influence the desensitization properties of the receptor channels. Thus, we considered the possibility that differences in the activity between homomeric GluR- $D_{i}$ and $-D_{o}$ receptor channels may play a role in determining the steady-state level of receptor on the plasma membrane. This is relevant as the expressed receptors are likely to be under tonic activation by L-glutamate present in the cell media (originating from hydrolysis of L-glutamine and from serum). Thus, we studied whether preincu-

\section{$\leftarrow$}

Figure 1. Consistent difference in the cell surface expression between the flip and flop isoforms of GluR-A and -D AMPA receptors. $A$, Biotinylation of surface expressed GluR-A and $-D$ flip/flop receptors in transfected HEK293 cells. Blots were probed with subunit specific antisera as indicated. $\boldsymbol{B}$, Surface and total staining of GluR-A splice variants in transfected $\operatorname{Cos} 7$ cells. All staining was against an $\mathrm{N}$-terminally encoded flag tag. The bar graph indicates the relative level of GluR-A flop cell surface and total expression as compared with the flip isoform. Error bars indicate mean $\pm S D ; n=4$. C, Surface and total staining of GluR-D splice variants in transfected Cos7 cells. All staining was against an N-terminally encoded flagtag. The bar graph indicates the relative level of GluR-D flop cell surface and total expression as compared with the flip isoform. Error bars indicate mean $\pm S D ; n=6$. $D$, Typical traces of whole-cell recordings of GluR-D flip or flop isoform homomeric receptors from transfected HEK293 cells; note the difference in $\mathrm{pA}$ scale. 
A
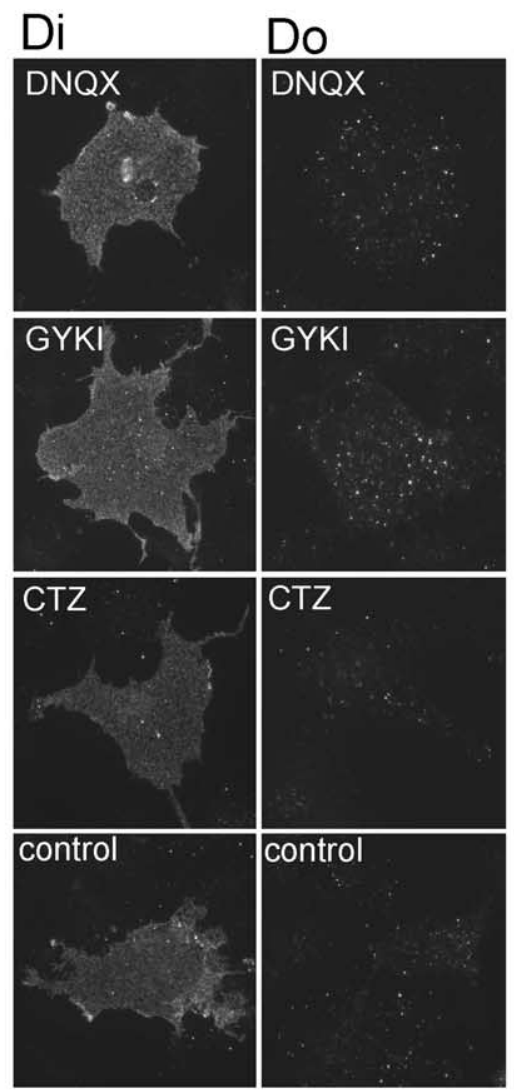
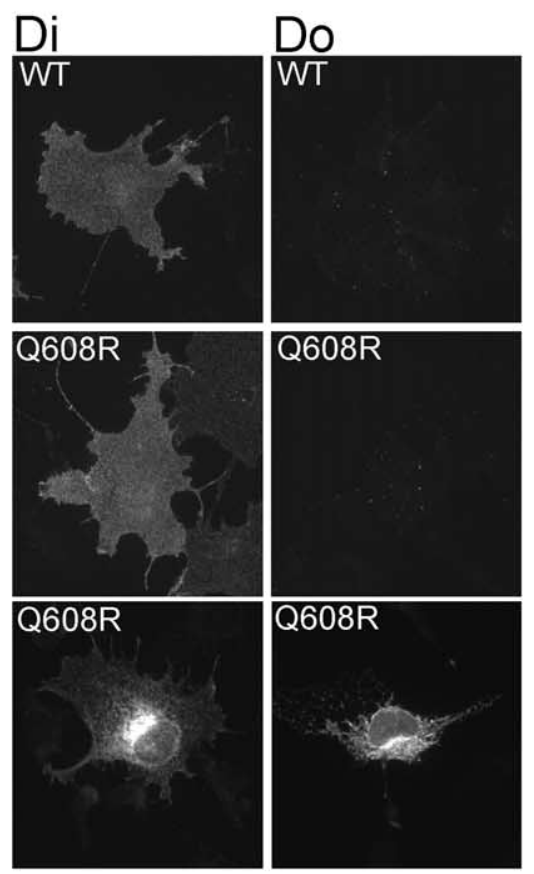

\section{C}
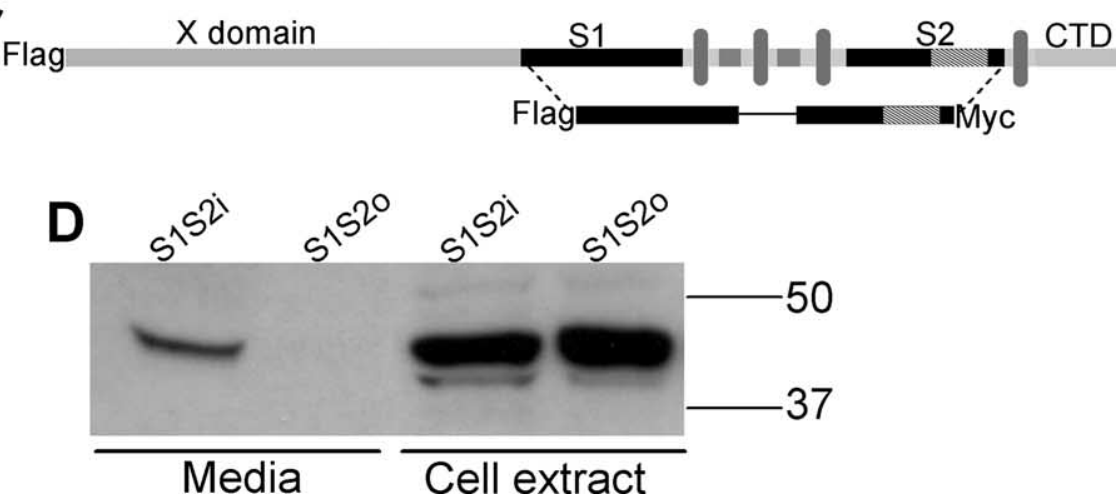

Figure 2. Surface expression of GluR-D isoforms is independent of receptor activity. $A$, Cell surface expression of GluR-D and $-D_{0}$ receptors in transfected Cos7 cells after incubation with the indicated receptor antagonists: $50 \mu \mathrm{m}$ DNQX, $100 \mu \mathrm{m}$ GYKI-52466, or potentiators, $50 \mu \mathrm{m}$ CTZ. Drugs were dissolved in ethanol; control is application of solvent only. Left, GluR-D labeling; right, GluR-D . All staining was against an $\mathrm{N}$-terminal flag-tag. $\boldsymbol{B}$, Point mutations within the channel pore $\mathrm{M} 2$ region. This is the equivalent mutation to the GluR-B endogenous RNA editing site, which blocks channel function. Both GluR-D isoforms were mutated. Left, GluR- $D_{i}$; right, GluR-D. The bottom panels show staining of mutants in permeabilized cells. All staining was against an N-terminal flag-tag. C, Behavior of full-length isoforms was mimicked by soluble, secretable GluR-D S1S2 constructs. A schematic of the full-length GluR-D primarily used in this study with the corresponding S1S2 constructbelow. The S1 and S2 regions are connected by a 13-residue linker; the flip/flop cassette is indicated. Xdomain, Residues 22-402; S1, residues 403-546; S2, residues 649-813; C-terminal domain (CTD), residues 837-902. D, Immunoblot showing expression and secretion of GluR-D S1S2 constructs. Media is HEK293 cell culture media harvested $40 \mathrm{~h}$ after transfection. Cell extract is Triton X-100 extract of the same cells. The blot was probed with anti-myc lgG.

bation with antagonists (DNQX and GYKI-52466) or an allosteric potentiator (cyclothiazide) affected the levels of GluR- $\mathrm{D}_{\mathrm{i}}$ or $-\mathrm{D}_{\mathrm{o}}$ receptors on cell surface. These experiments were performed in the absence of added L-glutamine but serum was required.
However, none of the tested compounds had significant influence on the surface expression of the GluR-D isoforms (Fig. 2A).

Next, we examined the effects of glutamine-to-arginine point mutation in the channel pore region; this mutation gives rise to inactive or very low conductance channels in homomeric expression (Swanson et al., 1997). The cellular localization of GluR-D $\mathrm{D}_{\mathrm{i}}$ and - $\mathrm{D}_{\mathrm{o}}$ (Q608R) mutants were equivalent to the wild-type GluR-D receptors, as shown by immunofluorescence staining: the flip versions were present on cell surface whereas the flop forms were largely intracellular (Fig. $2 B)$. These findings argue against differences in the functional activity as the cause for the observed splice isoform-specific pattern in the surface expression.

\section{Secretion of S1S2 ligand binding} domain is affected by splice isoform Our findings indicated that extracellular structures in wild-type GluR-D can strongly influence the cellular localization of the receptor in transfected cells, although AMPA receptor trafficking is generally believed to be under guidance of motifs in the cytoplasmic carboxy terminal tails. This prompted us to study whether the flip/flop segment can exert an effect on cellular transport which is independent of contributions from intracellular and/or transmembrane segments of the receptor. The ligand-binding domain of AMPA receptors, including the flip/flop segment, can be expressed separately as an S1S2 fusion protein and targeted for secretion by use of a signal peptide (Arvola and Keinänen, 1996) (Fig. 2C). Thus, we examined the relative secretion levels of flip and flop forms of GluR-D S1S2 fusion protein from transfected HEK293 cells. Consistent with the behavior of full-length receptors, $\mathrm{S} 1 \mathrm{~S} 22_{\mathrm{i}}$ was readily secreted into the cell culture medium, whereas $\mathrm{S} 1 \mathrm{~S} 2$ 。 was not (Fig. 2D). Quantification of immunoblots revealed that $\mathrm{S} 1 \mathrm{~S} 2{ }_{\mathrm{o}}$ was present in the medium at $10 \pm 7.3 \%$ of $S 1 S 2_{\mathrm{i}}$ levels $(n=7)$. The greater amount of $\mathrm{S} 1 \mathrm{~S} 2{ }_{\mathrm{i}}$ in the culture medium (collected at $40 \mathrm{~h}$ after transfection) was not caused by higher expression level, as Triton X-100 extracts of transfected cells contained similar amounts of flip and flop isoforms (Fig. $2 D)$. Neither earlier (16 and $24 \mathrm{~h}$ ) nor later (64 and $72 \mathrm{~h}$ ) harvesting of the culture medium led to better detection of S1S2 ${ }_{\mathrm{o}}$, implying that the difference is not caused by lower stability of flop in the medium or by substantially slower (but efficient) secretion of the flop form. Hence, secretion of the soluble ligand-binding domain of GluR-D followed the same dependency on splice isoform as the surface expression of the full-length receptor. 


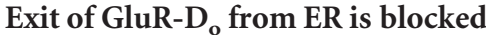

Next, we examined the localization of the transport block for the flop isoform in more detail. We used low-temperature-induced protein transport block to study the accumulation of expressed protein in cellular compartments, incubation at $15^{\circ} \mathrm{C}$ is known to promote accumulation of proteins in ER exit sites/pre-Golgi compartment (Kuismanen and Saraste, 1989). Figure 3, $A$ and $B$, shows costaining of N-terminally myc-tagged GluR- $\mathrm{D}_{\mathrm{i}}$ and $-\mathrm{D}_{\mathrm{o}}$ with specific cellular markers after transport blockade. At $15^{\circ} \mathrm{C}$ both isoforms showed good colocalization with ER protein BAP31 ( $\mathrm{Ng}$ et al., 1997). In contrast, only GluR-D $\mathrm{D}_{\mathrm{i}}$ colocalized with Sec23p, a component of COPII coat and a marker of the ER exit sites (Tang et al., 2005), demonstrating that GluR-D but not GluR- $D_{\mathrm{o}}$ is recruited in the ER exit sites (Fig. $3 A, B$, middle rows, supplemental Fig. 2, available at www.jneurosci.org as supplemental material). The above findings were strengthened by colocalization of GluR- $\mathrm{D}_{\mathrm{i}}$ but not GluR- $\mathrm{D}_{\mathrm{o}}$ with the cis-Golgi marker protein p58 (Bloom and Brashear, 1989) at $15^{\circ} \mathrm{C}$ (Fig. $3 A, B$, bottom rows).

Treatment with endoglycosidase $\mathrm{H}$ (EndoH), which digests high-mannose core oligosaccharides on proteins retained in the ER or cis-Golgi, provided independent biochemical evidence for the observed localization of the splice isoforms. GluR-D $\mathrm{D}_{\mathrm{o}} \mathrm{mi}-$ grated as a single $\sim 115 \mathrm{kDa}$ band in SDS-PAGE, which was totally converted to a $\sim 100 \mathrm{kDa}$ species by EndoH (Fig. $3 C$ ). In contrast, GluR-D $D_{\mathrm{i}}$ appeared as a broad $\sim 115-120 \mathrm{kDa}$ band, which after EndoH digestion resolved into equally intense $\sim 120$ $\mathrm{kDa}$ and $\sim 100 \mathrm{kDa}$ bands, representing EndoH-insensitive and the EndoH-sensitive fractions, respectively (Fig. $3 C$ ). The complete EndoH-sensitivity of the flop isoform indicates an absence of Golgi-specific processing, whereas the insensitivity of half of GluR- $\mathrm{D}_{\mathrm{i}}$ to EndoH is consistent with transport via Golgi. Together, these experiments suggest the recruitment to ER exit sites as the step which is specifically blocked in the transport of GluR-D.

\section{Identifying the structural determinants for the isoform-} specific localization difference

There are 11 sequence differences between the GluR- $D_{i}$ and $-D_{0}$ constructs used in these experiments: 10 in the flip/flop exon and one caused by RNA editing (arginine in flip, glycine in flop) at position 765 immediately preceding the flip/flop segment (Lomeli et al., 1994) (Fig. 4A). To identify the residues responsible for the trafficking difference chimeric constructs in which blocks of 3-5 residues had been swapped between flip and flop (Fig. 4A) were initially examined. For experimental convenience, GluR-D constructs lacking the X domain (residues 22-402) were used for this analysis. Removal of this domain has no significant effects on assembly and trafficking of GluR-D homomeric receptors (Pasternack et al., 2002) (supplemental Fig. 3, available at www. jneurosci.org as supplemental material). Immunofluorescence staining of the transfected Cos7 cells indicated that Block 1 (including the R/G editing site) and Block 3, representing the most obvious difference between flip (PKDSG) and flop (SGGGD), do not contribute to the observed difference between flip and flop isoforms (Fig. $4 \mathrm{~B}$ ). In contrast, swapping block 2 reversed the surface expression behavior of the GluR- $D_{i}$ mutant to flop-like and vice versa (Fig. $4 B$, middle). Clear staining in permeabilized cells showed that all the mutants were expressed similar levels (Fig. $4 B$ ).

The three sequence differences in block 2 were exchanged individually, in both GluR- $\mathrm{D}_{\mathrm{i}}$ and $-\mathrm{D}_{\mathrm{o}}$ backgrounds, and analyzed by immunofluorescence microscopy (Fig. 4C). Surpris-
A
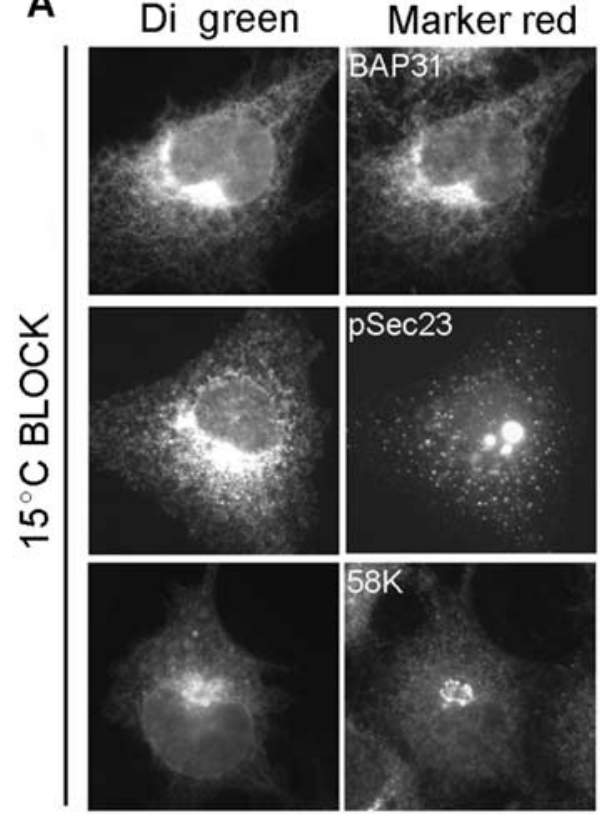

pSec23

B
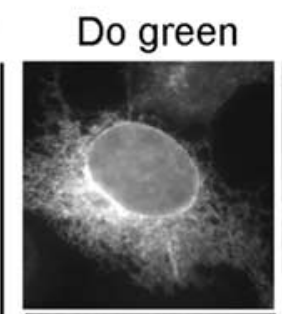

Marker red
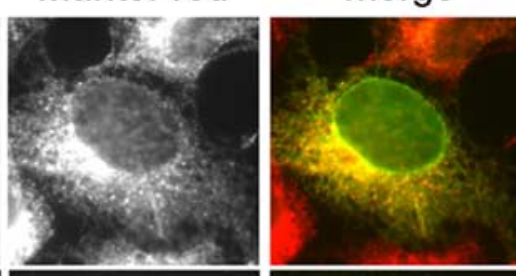

\begin{tabular}{l} 
צ \\
0 \\
\hline \\
m \\
0 \\
0 \\
n
\end{tabular}
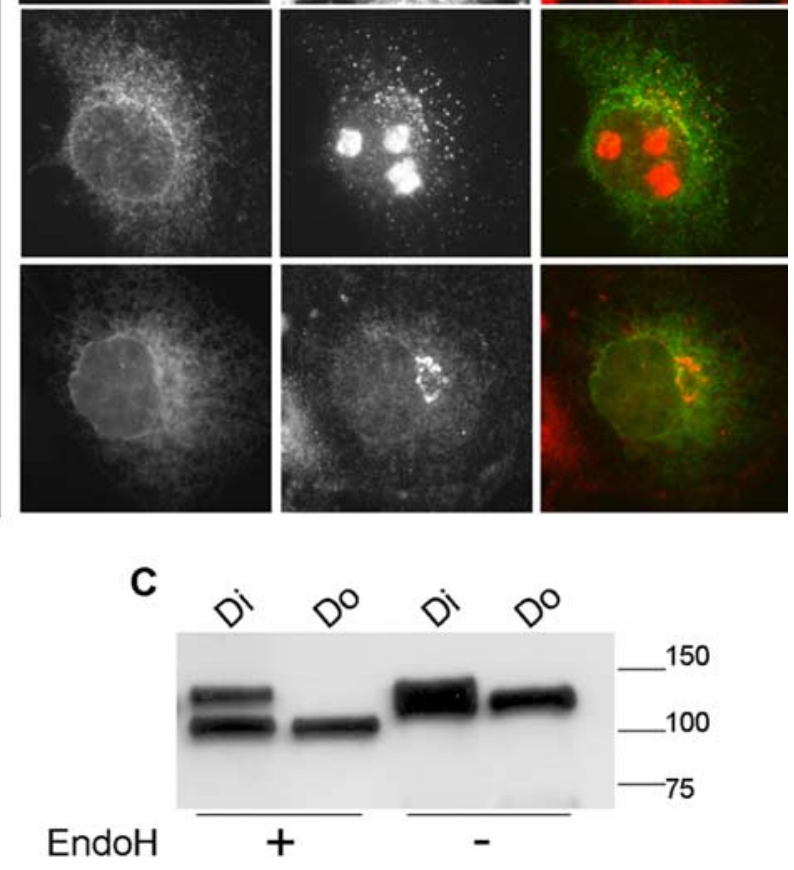

Figure 3. Subcellular localization of GluR-D flip and flop isoforms. $A, B$, Trafficking block and immunostaining of GluR- $D_{i}(\boldsymbol{A})$ and GluR- $D_{0}(\boldsymbol{B})$ with costaining of specific cellular markers in $\operatorname{Cos} 7$ cells; the $15^{\circ} \mathrm{C}$ temperature block promotes accumulation in ER and prevents proteins from processing through the Golgi. BAP31 is an endogenous ER protein; $\mathrm{pSec} 23$ is a COPII coat protein and a marker for ER exit sites; $\mathrm{p} 58$ is an endogenous cis-Golgi protein. GluR-D staining, against $\mathrm{N}$-terminal tag, is green and respective cell markers are red in the merged images. C, Differences in cellular localization of the flip and flop isoforms are reflected in the maturity of their glycosylation. Cell extracts from transfected HEK293 cells expressing N-terminal flag-tagged GluR-D or $-D_{0}$ were subject to $E n d o H$ treatment to cleave immature glycosylation. The blot was probed with anti-flag M2 lgG. 
A

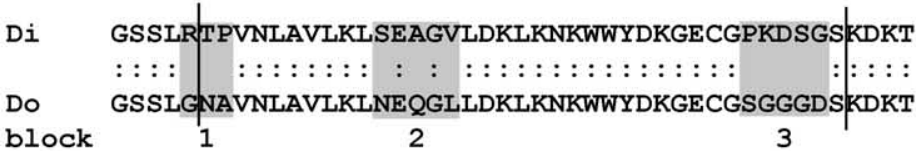

B

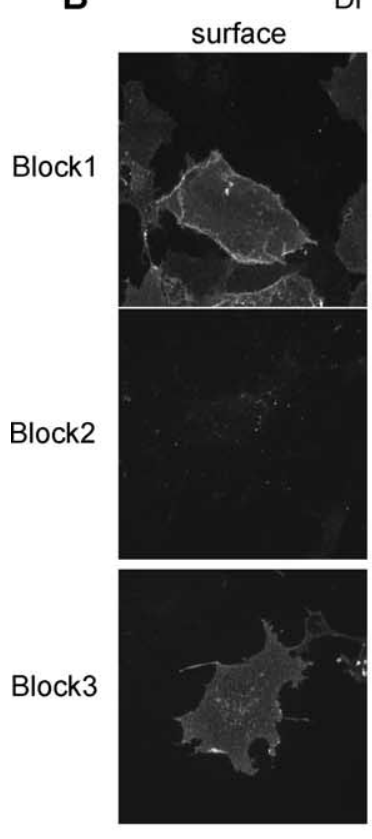

C
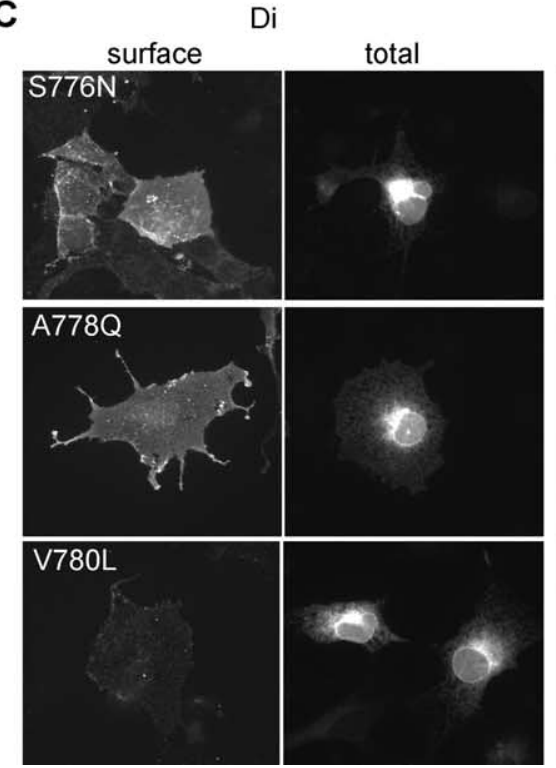

total
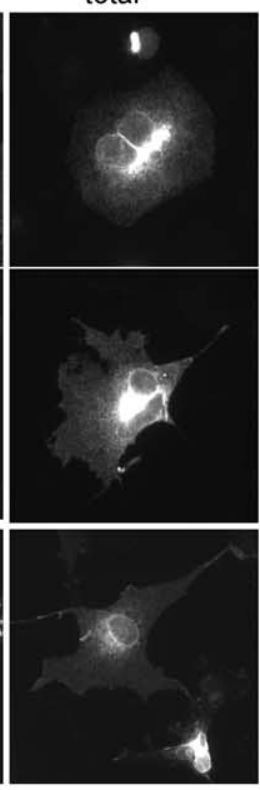

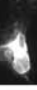
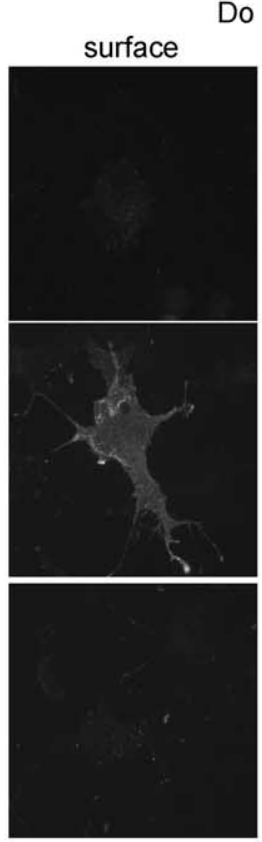

Do
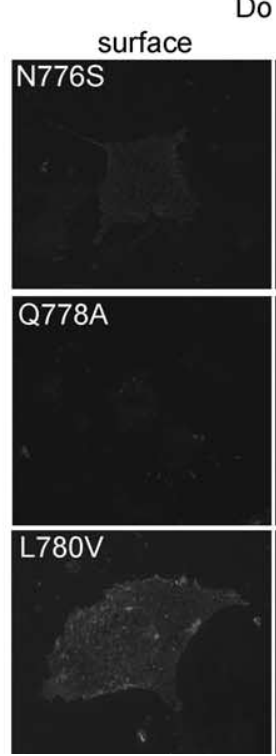

Do

Figure 4. Identification of the structural determinants for the trafficking difference between GluR-D flip and flop. $A$, The primary sequence of GluR-D of flip/flop segment, indicating the three sites of variation. Block 1 includes the R/G RNA edited site just before the flip/flop exon. $\boldsymbol{B}$, Immunofluorescence staining of GluR-D flip/flop chimeras in transfected Cos7 cells. The respective "blocks" were switched between the isoforms, such that the flop sequence was expressed in the flip background and vice versa. Total staining demonstrates that all the mutations were expressed by the cells. All staining was against an N-terminal flag-tag. $C$, Immunofluorescence staining of GluR-D flip/flop single point mutations from "block 2" in transfected Cos 7 cells. The total staining shows that the mutants were expressed by the cells. All staining was against the $\mathrm{N}$-terminal flag-tag.

ingly, the superficially minor difference at position 780 , valine in flip and leucine in flop, appeared as the strongest determinant for the cellular localization. Single residue swapping at position 780 imparted the surface expression characteristics of the opposing
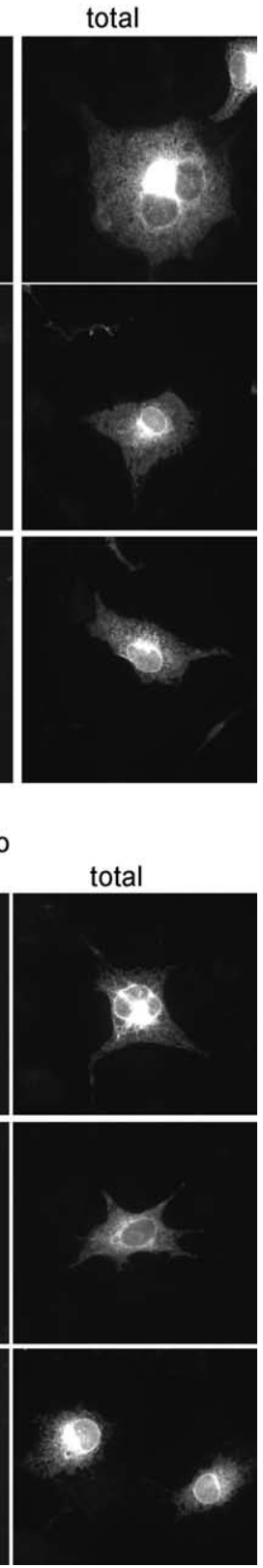

splice isoform, although not completely. In contrast, single point mutations at the other two differences in block $2, \mathrm{~S} / \mathrm{N}$ at position 776 and $\mathrm{Q} / \mathrm{A}$ at position 778 , did not significantly alter the surface expression patterns of the parental constructs.

Characterization of full-length GluR$\mathrm{D}_{\mathrm{i}}(\mathrm{V} 780 \mathrm{~L})$ and $-\mathrm{D}_{\mathrm{o}}(\mathrm{L} 780 \mathrm{~V})$ confirmed the importance of residue 780 as a major determinant for cellular localization of GluR-D isoforms (Fig. 5). Mutation of leucine to valine dramatically increased the surface expression of GluR- $D_{0}$ to $\sim 50 \%(51 \% \pm 14 ; n=6)$ of GluR- $D_{i}$ level; the reverse, valine to leucine, decreased the amount of surface exposed GluR-D $\mathrm{D}_{\mathrm{i}}$ to about half $(49 \% \pm 11 ; n=6)$ (Fig. $5 A)$. Similar results were obtained on the effect of valine/leucine exchange at residue 780 by biotinylation analysis (Fig. $5 B$ ) or from peak whole-cell currents measurement (Fig. 5C,D). Notably, the mutant channels exhibited desensitization kinetics typical of their wild-type counterparts, with GluR- $D_{0}$ desensitizing 2-3 times faster than flip (Fig. 5D). These results are consistent with earlier mutation studies on desensitization behavior of AMPA receptor flip and flop channels (Quirk et al., 2004). Finally, it was of interest to determine the role of residue 780 in the secretion of the soluble S1S2 ligand-binding domain. Switching the Val/Leu residues in the GluR-D S1S2 constructs did not alter the overall expression levels (Fig. 5E) (data not shown), but V780L mutation diminished secretion of $S 1 S 2_{i}$ to $30 \pm 14 \%(n=4)$ of $\mathrm{S} 1 \mathrm{~S} 2_{\mathrm{i}}$ wild-type level, whereas $\mathrm{L} 780 \mathrm{~V}$ mutation doubled the accumulation of S1S2。 in the culture medium $(202 \pm 53 \% ; n=4)$ of wild-type $S 1 S 2_{\mathrm{o}}(n=4)$ (Fig. $5 E$ ). However, $S 1 S 2_{\mathrm{i}}(\mathrm{V} 780 \mathrm{~L})$ was still secreted from the cells more efficiently than $\mathrm{S}_{1 S 2} 2_{\mathrm{o}}$ (L780V) (Fig. 5E).

\section{Endogenous modulation of isoform- specific GluR-D trafficking}

In the absence of flip- or flop-specific antibodies, possible differences in the localization of natively expressed isoforms remain unknown. Therefore, we examined the localization of GFP-tagged GluR- $D_{i}$ and $-D_{\mathrm{o}}$ in transfected neurons. In Cos7 and HEK293 cells GFP-tagged GluR-D isoforms behaved in a manner identical to their flag-tagged counterparts (data not shown). However, in mouse cortical neurons, the overall expression levels and numbers of surface exposed receptors were not significantly different for GluR- $D_{i}$ and $-D_{o}$ as judged by GFP fluorescence and anti-GFP immunostaining in nonpermeabilized cells, respectively (Fig. 6, supplemental Fig. 4, available at www.jneurosci.org as supplemental material). This dramatic dif- 
A
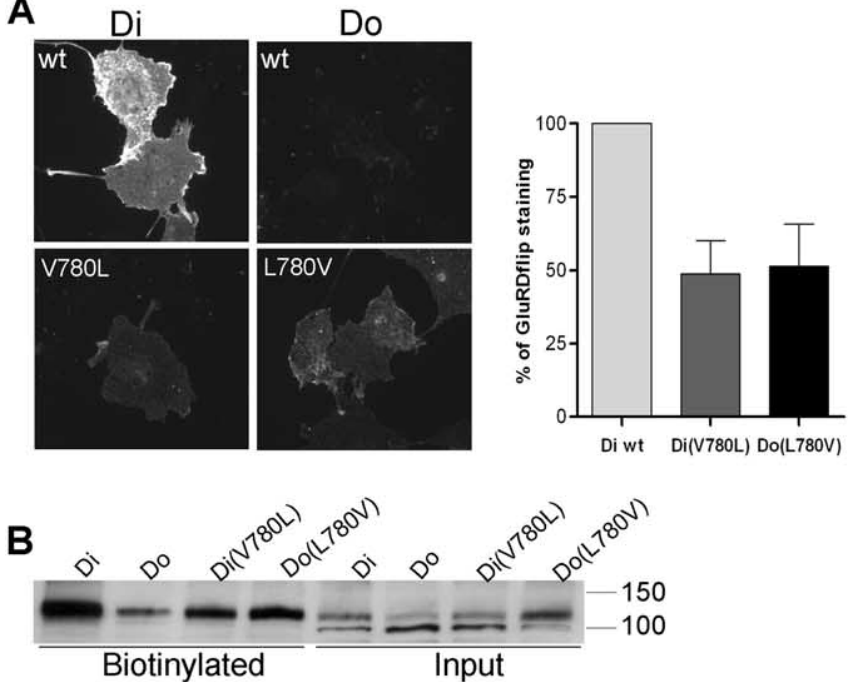

C
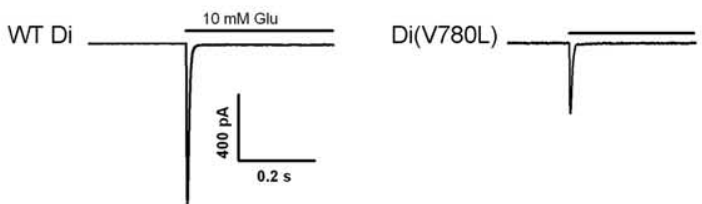

WT Do

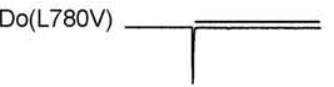

D
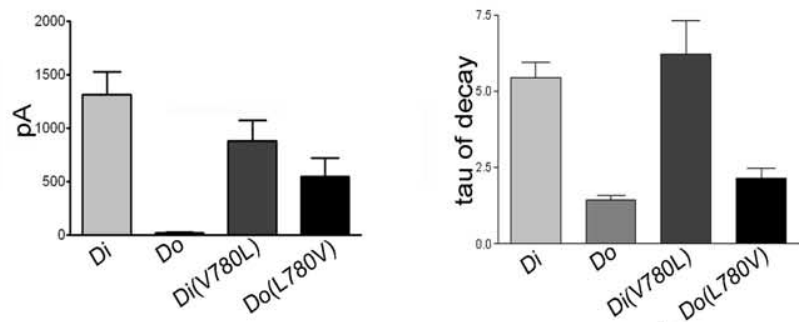

E

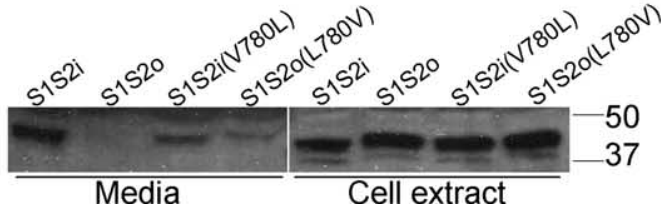

Figure 5. Analysis of GluR- $D_{i}(V 780 \mathrm{~L})$ and $-D_{0}(\mathrm{~L} 780 \mathrm{~V})$ point mutants. $A$, Direct comparison of surface expression of homomeric full-length GluR- $D_{i}$ and $-D_{0}$ wild-type receptors and GluR$D_{i}(V 780 \mathrm{~L})$ and $-D_{0}(\mathrm{~L} 780 \mathrm{~V})$ mutant receptors in Cos7 cells. Quantification of the cell surface expression level of the mutant receptors as compared with the wild-type GluR-Di is shown in the bar graph. Error bars indicate mean $\pm S D ; n=6$. B. Biotinylation of surface expressed GluR$D_{i}(\mathrm{~V} 780 \mathrm{~L})$ and $-D_{0}(\mathrm{~L} 780 \mathrm{~V})$ receptors in transfected HEK293 cells. The blot was probed with anti-GluR-BD ${ }_{\text {LoNG }}$ antisera. C, Typical sample traces from whole-cell recordings of homomeric wild-type GluR- $D_{i}$ and $-D_{0}$ and mutant GluR- $D_{i}(V 780 L)$ and $-D_{0}(L 780 V)$ receptors from transfected HEK293 cells, after application of saturating concentration of glutamate (10 mm). D, Comparison of maximal whole cell amplitudes and tau of decay values from HEK293 cells transfected with the constructs indicated. Error bars indicate mean \pm SEM; $n=5-8$. $\boldsymbol{E}$, The (V780L)/(L780V) point mutations also alter the trafficking of the GluR-D S1S2 constructs in transfected HEK293 cells. The immunoblot was probed with anti-myc lgG.

ference between transfected primary neurons and mammalian cell lines suggests that neuron-specific mechanisms can circumvent the block in the processing of the flop isoform. An obvious candidate is stargazin and/or other members of the family, which are known to be expressed in cortical neurons (Nicoll et al.,

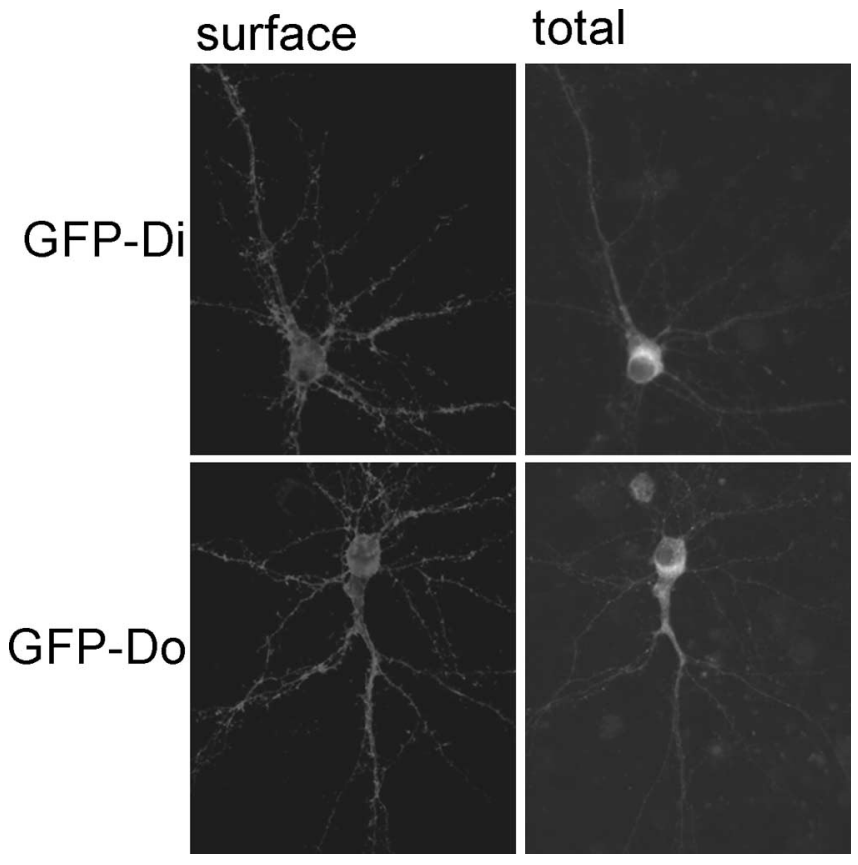

Figure 6. Expression of GFP-tagged GluR- $D_{i}$ and $-D_{0}$ in transfected primary neurons. Typical micrographs of mouse cortical neurons expressing GFP-GluR- $D_{i}$ or $-D_{0}$ are shown. Transfected neurons were identified by GFP fluorescence (green). Surface expression was examined by labeling nonpermeabilized cells with anti-GFP IgG (red).

2006). Hence, we examined whether coexpression with stargazin would affect surface expression of GluR-D isoforms. In contrast to the singly expressed receptor, GluR- $\mathrm{D}_{\mathrm{o}}$ coexpressed with stargazin became readily detectable on cell surface by immunofluorescence or by surface biotinylation, whereas stargazin had no significant effect on GluR-D $\mathrm{D}_{\mathrm{i}}$ (Fig. $7 A, B$ ). The coexpression and costaining of NMDAR1 with GluR-D, a negative and technical control, had as expected no effect on GluR-D isoform localization. Quantification of biotinylation immunoblots indicated that GluR-D $D_{0}$ was expressed at $89 \% \pm 4.7(n=3)$ of GluR-D levels (Fig. $7 B$ ). Thus, the difference between flip and flop surface expression is mostly or totally eliminated by coexpression with stargazin. The point mutants GluR- $\mathrm{D}_{\mathrm{i}}(\mathrm{V} 780 \mathrm{~L})$ and GluR-D $(\mathrm{L} 780 \mathrm{~V})$ were also expressed at similar levels: $\mathrm{D}_{\mathrm{o}}(\mathrm{L} 780 \mathrm{~V})$ at $110 \% \pm 23$ of $\mathrm{D}_{\mathrm{i}}(\mathrm{V} 780 \mathrm{~L})(n=3)$ (Fig. $\left.7 C\right)$. Interestingly, in the presence of overexpressed stargazin a substantial amount of incompletely processed wild-type and mutated GluR-D was observed, suggesting that association with stargazin may influence the glycosylation or lead to a less stringently controlled processing of the receptor (Fig. $7 B, C$ ). Together, the above data demonstrate that the flop isoform-specific transport defect can be overcome by stargazin.

\section{Surface transport of flip/flop-heteromeric GluR-D receptors}

Finally, we examined whether coexpression with the flip isoform would promote transport of GluR-D $\mathrm{D}_{\mathrm{o}}$ to cell surface. Biotinylation affects the immunoreactivity of extracellular epitopes; thus, we used flip and flop forms of the short-tailed variant, GluR$\mathrm{D}_{\text {SHORT }}$ (Gallo et al., 1992), for these experiments. The C terminus of GluR-D $\mathrm{D}_{\text {SHORT, which is }} 81 \%$ identical to GluR-B, is recognized by commercial GluR2/3 antibody, but not by anti-GluR-BD LONG $_{\text {(supplemental Figs. 1, 5, available at www. }}$ jneurosci.org as supplemental material). First, we confirmed that surface expression of GluR-D with either long or short C-terminal segments are similarly dependent on the flip/flop 

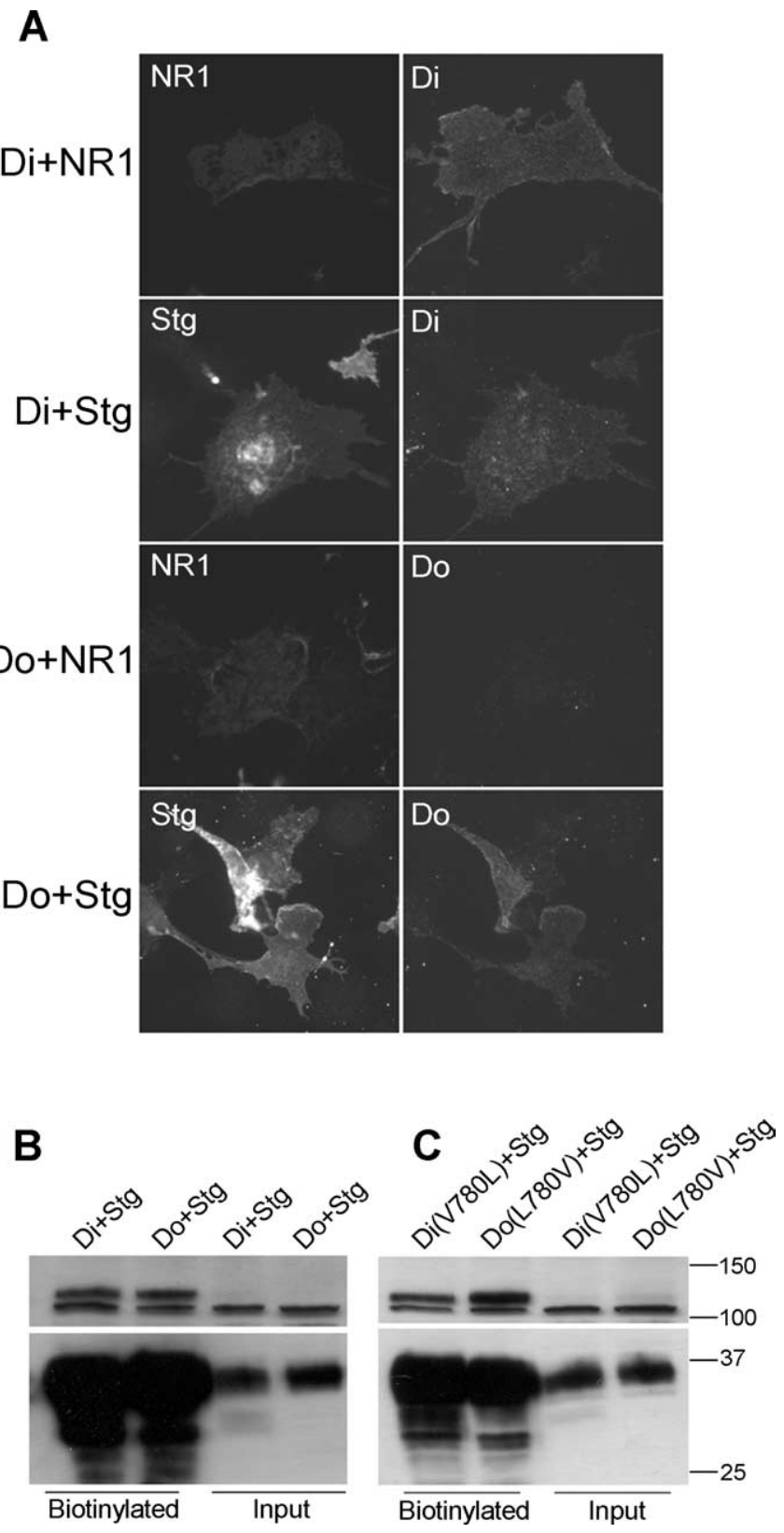

Figure 7. Coexpression of stargazin drives GluR-D to the cell surface. $A, \operatorname{Cos} 7$ cells were cotransfected with the indicated constructs and costained with anti-flag M2 for GluR-D followed by either anti-NMDAR1 (NR1) IgG or anti-stargazin lgG. GluR-D labeling (right) was done on nonpermeabilized cells. Stargazin (Stg) and NR1 labeling (left) was after permeabilization of cells. $\boldsymbol{B}$, Biotinylation of surface expressed wild-type GluR-D receptors and stargazin in cotransfected HEK293 cells. Cells were cotransfected with the indicated constructs. The top blot was probed with anti-BD $\mathrm{LONG}_{\mathrm{L}}$ sera; bottom blot with anti-stargazin sera. $C$, Biotinylation of surfaceexpressed point mutant GluR-D receptors and stargazin in cotransfected HEK293 cells. Cells were cotransfected with the indicated constructs. The top blot was probed with anti-BD ${ }_{\text {LONG }}$ sera; bottom blot with anti-stargazin sera.

splice form (supplemental Fig. 5A, available at www.jneurosci. org as supplemental material). We then examined the behavior of the heteromers. The surface level of GluR-D $\mathrm{D}_{\mathrm{o}}$ was almost two times higher when coexpressed with GluR-D SHORT $^{-f l i p}$ (190 \pm $52 \% ; n=4)$ than when coexpressed with GluR-D SHORT $^{- \text {flop, and }}$ reached $65 \pm 19 \%(n=4)$ of the level of homomeric GluR- $\mathrm{D}_{\mathrm{i}}$ (supplemental Fig. 5B, available at www.jneurosci.org as supplemental material). Transport of GluR- $D_{i}$ to cell surface appeared unaffected or only slightly decreased after coexpression with the short-tailed flop isoform (supplemental Fig. 5C, available at www.jneurosci.org as supplemental material). These findings indicate that coassembly with the flip isoform augments maturation and trafficking to cell surface of GluR- $\mathrm{D}_{\mathrm{o}}$ subunits.

\section{Discussion}

The present results demonstrate a selective block of GluR- $\mathrm{D}_{\mathrm{o}}$ isoform in the ER in several cell lines leading to a remarkable difference in the surface expression of homomeric flip and flop receptors. The trafficking difference (1) is not dependent on receptor activity, (2) is independent of the presence of transmembrane and cytoplasmic domains, (3) can be corrected by over expression of stargazin, and (4) is mainly determined by the amino acid residue at position 780, leucine in flop, and valine in flip. These findings indicate that stringency of control at ER exit level is regulated in a splice isoform-dependent manner by molecular interactions in the ER luminal space. The current results have implications for AMPA receptor structure/function and for subunit/isoform-specific assembly and transport mechanisms.

Subunit-specific differences in AMPA receptor trafficking generally depend on interactions between the unique cytoplasmic carboxy terminal tails of the receptor subunits and components of the cellular transport machinery (Passafaro et al., 2001; Shi et al., 2001); accordingly, less attention has been paid on the possible role of the ectodomain. Partial deletions in the N-terminal X domain of GluR-A (Xia et al., 2002) and GluR-D subunits (Pasternack et al., 2002) inhibit surface expression in transfected cells. However, for GluR-D this is likely caused by impairment of folding and assembly rather than loss of specific trafficking signals, as a GluR-D deletion variant which lacks the whole X domain is transported efficiently to cell surface and is fully capable of forming active channels (Pasternack et al., 2002). Although agonist binding is obligatory for kainate receptor transport to the cell surface (Mah et al., 2005; Valluru et al., 2005), it is unlikely to contribute to the isoform-specific differences observed in this study because the flip and flop exon-encoded segments lay outside the ligand binding cleft (Armstrong et al., 1998) and the two isoforms have similar in vitro binding ligand properties (Arvola and Keinänen, 1996). Furthermore, theoretically saturating concentrations of an antagonist or an allosteric potentiator or the presence of channel function abolishing mutation (R608Q) had no significant effect on the surface expression of the GluR-D isoforms, implying that functional activity of the receptor does not contribute to the splice form-specific differences. As local intracellular concentrations of antagonist or glutamate remain unknown, binding site occupancy may still play a permissive but isoform-independent role in receptor transport.

The exit from ER has emerged as an important regulatory step in the early trafficking of ionotropic glutamate receptors. Spliceform dependent control of ER exit via inclusion or removal of intracellular C-terminal ER retention/retrieval motifs has been described for certain NMDA and kainate receptor subunits (Okabe et al., 1999; Xia et al., 2001; Gallyas et al., 2003; Hayes et al., 2003; Ren et al., 2003). Specific ER retention signals have not been found in the $\mathrm{C}$ termini of AMPA receptor subunits, but our finding that ER exit of GluR-D $D_{0}$ is blocked in three different cell lines that are permissive to efficient surface expression of GluR- $\mathrm{D}_{\mathrm{i}}$ demonstrates that exit from ER is likely to be a regulated step for AMPA receptors as well. Previously, it has been reported that homomeric GluR-B channels fully edited at Q/R site are retained in ER in neurons (Greger et al., 2002, 2003). The equivalent mutation (R608Q) in GluR- $D_{i}$ did not have the 
same effect, perhaps because of subunit or expression systemspecific differences.

Expression of native AMPA receptors on the surface of cerebellar granule cells is dependent on stargazin, a calcium channel $\gamma$-subunit homolog (Letts et al., 1998; Chen et al., 1999; Hashimoto et al., 1999). Stargazin and its closely related $\gamma 3, \gamma 4$ and $\gamma 8$ paralogs interact directly with AMPA receptors to promote their transport to cell surface (Chen et al., 2000; Tomita et al., 2003) to modulate channel function (Priel et al., 2005; Tomita et al., 2005). It was reported previously that stargazin is able to augment surface expression of GluR-A AMPA receptors via a chaperonelike action at ER exit level (Vandenberghe et al., 2005). Two current findings lend support to this notion. First, unlike in cell lines, surface expression levels of GFP-tagged GluR-D $D_{0}$ and GluR-D did not differ significantly in transfected cortical neurons, known to express stargazin family proteins (Tomita et al., 2003). Second, coexpression with stargazin restored the transport to cell surface of GluR-D in Cos7 and HEK293 cells to the same level with GluR- $\mathrm{D}_{\mathrm{i}}$. Interestingly, stargazin did not affect the surface expression of GluR- $\mathrm{D}_{\mathrm{i}}$. These findings indicate that stargazin is able to alleviate the block in the ER exit of the flop isoform, whereas the transport of GluR- $\mathrm{D}_{\mathrm{i}}$ is unhindered by such a mechanism.

Mutation analysis pointed to residue 780 as the primary determinant for the splice form-dependent difference in transport efficiency, the individual contributions of all other residues being insignificant. An additional minor involvement of other isoformspecific residues is suggested by the finding that single residue exchange at position 780 did not completely reverse the surface expression to correspond to the other splice form. In the crystal structure of GluR-B, S1S2 fusion protein (flop isoform) leucine 779 , equivalent to Leu-780 in GluR- $\mathrm{D}_{\mathrm{o}}$, is located at the $\mathrm{N}$ terminus of helix K and is pointing outwards (Armstrong et al., 1998). In contrast, most other flip/flop-specific residues lie on helix J, which packs against structures at the C-terminal end of the S1 segment in a dimer interface between two ligand-binding domains, the stability of which correlates with the desensitization rate of the corresponding channels (Sun et al., 2002). Consistent with the predicted location, residues 780 in GluR-D (present study) and 779 in GluR-B (Quirk and Nisenbaum, 2003; Horning and Mayer, 2004) do not contribute to desensitization-rate differences between flip and flop isoforms.

Our finding that coexpression with the flip isoform increases surface expression of GluR- $D_{0}$ is in agreement with a previous report that heteromeric flip/flop combinations are favored over homomeric flop receptors for coexpression of GluR-A/B (Brorson et al., 2004). Mechanistically, inefficient transport of homomeric flop receptors may be caused by inefficient folding/assembly or by an absence of (splice form) specific transport proteins/ chaperones. Naturally, these alternatives are not mutually exclusive because the terminal stages of folding and assembly may take place simultaneously with early steps in trafficking. The predicted location of residue 780 is, with the present limited structural information, consistent with a functional role both in intramolecular interactions involved in the tetrameric assembly and in interactions with external molecules in the luminal space of the secretory pathway. Several current findings, however, argue against a fundamental folding/assembly problem as the cause for the poor surface expression of the flop isoform. Importantly, the soluble S1S2 fusion proteins exist as monomers even in high protein concentrations (Abele et al., 1999; Sun et al., 2002) and yet their secretion follows the same dependency on splice isoform and on residue 780 as observed in the full-length receptor, arguing strongly for a common underlying mechanism. Furthermore, transport block of GluR- $\mathrm{D}_{\mathrm{o}}$ is reversible, being totally eliminated by stargazin coexpression (see below). Finally, GluR- $\mathrm{D}_{\mathrm{o}}$ is able to form functional channels in good agreement with its level on cell surface. None of these findings rule out a role for residue 780 in the assembly, but they are best consistent with an interaction with isoform-specific ER luminal proteins which either prevent the exit of the flop isoform from the ER, or recruit the flip isoform to ER exit sites. This raises the possibility that in neurons these mechanisms may facilitate an individual regulation of the flip/ flop isoform content of synaptic (and extrasynaptic) receptors. Single cell PCR studies suggest that a neuron can simultaneously express both flip and flop isoforms of AMPA receptors (Angulo et al., 1997). The lack of isoform/subunit-specific antibodies, however, has prevented a direct flip/flop isoform typing of endogenous receptor proteins.

In conclusion, we demonstrated a remarkable flip/flop splice form-specific difference in the cellular transport of GluR-D AMPA receptors. For both homomeric full-length membrane channel and the monomeric secreted ligand-binding domain, the flip isoform is secreted efficiently, whereas the flop isoform is mostly retained in the ER. The block in the transport of the flop isoform can be relieved by coexpression of stargazin, a known regulator of AMPA receptor trafficking. Our findings indicate that alternative splicing of the flip and flop exons may regulate AMPA receptor trafficking through ER luminal mechanisms capable of discriminating between the isoforms.

\section{References}

Abele R, Svergun D, Keinänen K, Koch MH, Madden DR (1999) A molecular envelope of the ligand-binding domain of a glutamate receptor in the presence and absence of agonist. Biochemistry 38:10949-10957.

Angulo MC, Lambolez B, Audinat E, Hestrin S, Rossier J (1997) Subunit composition, kinetic, and permeation properties of AMPA receptors in single neocortical nonpyramidal cells. J Neurosci 17:6685-6696.

Armstrong N, Sun Y, Chen GQ, Gouaux E (1998) Structure of a glutamatereceptor ligand-binding core in complex with kainate. Nature 395:913-917.

Arvola M, Keinänen K (1996) Characterization of the ligand-binding domains of glutamate receptor (GluR)-B and GluR-D subunits expressed in Escherichia coli as periplasmic proteins. J Biol Chem 271:15527-15532.

Bloom GS, Brashear TA (1989) A novel 58-kDa protein associates with the Golgi apparatus and microtubules. J Biol Chem 264:16083-16092.

Bredt DS, Nicoll RA (2003) AMPA receptor trafficking at excitatory synapses. Neuron 40:361-379.

Brorson JR, Li D, Suzuki T (2004) Selective expression of heteromeric AMPA receptors driven by flip-flop differences. J Neurosci 24:3461-3470.

Cai C, Li H, Rivera C, Keinänen K (2006) Interaction between SAP97 and PSD-95, two Maguk proteins involved in synaptic trafficking of AMPA receptors. J Biol Chem 281:4267-4273.

Chen L, Bao S, Qiao X, Thompson RF (1999) Impaired cerebellar synapse maturation in waggler, a mutant mouse with a disrupted neuronal calcium channel gamma subunit. Proc Natl Acad Sci USA 96:12132-12137.

Chen L, Chetkovich DM, Petralia RS, Sweeney NT, Kawasaki Y, Wenthold RJ, Bredt DS, Nicoll RA (2000) Stargazin regulates synaptic targeting of AMPA receptors by two distinct mechanisms. Nature 408:936-943.

Coleman SK, Cai C, Mottershead DG, Haapalahti JP, Keinänen K (2003) Surface expression of GluR-D AMPA receptor is dependent on an interaction between its C-terminal domain and a 4.1 protein. J Neurosci 23:798-806.

Collingridge GL, Isaac JT, Wang YT (2004) Receptor trafficking and synaptic plasticity. Nat Rev Neurosci 5:952-962.

Gallo V, Upson LM, Hayes WP, Vyklicky Jr L, Winters CA, Buonanno A (1992) Molecular cloning and development analysis of a new glutamate receptor subunit isoform in cerebellum. J Neurosci 12:1010-1023.

Gallyas Jr F, Ball SM, Molnar E (2003) Assembly and cell surface expression of KA-2 subunit-containing kainate receptors. J Neurochem 86:1414-1427.

Greger IH, Khatri L, Ziff EB (2002) RNA editing at arg607 controls AMPA receptor exit from the endoplasmic reticulum. Neuron 34:759-772. 
Greger IH, Khatri L, Kong X, Ziff EB (2003) AMPA receptor tetramerization is mediated by Q/R editing. Neuron 40:763-774.

Grosskreutz J, Zoerner A, Schlesinger F, Krampfl K, Dengler R, Bufler J (2003) Kinetic properties of human AMPA-type glutamate receptors expressed in HEK293 cells. Eur J Neurosci 17:1173-1178.

Harlow E, Lane D (1988) Antibodies: a laboratory manual. Cold Spring Harbor, NY: Cold Spring Harbor Laboratory.

Hashimoto K, Fukaya M, Qiao X, Sakimura K, Watanabe M, Kano M (1999) Impairment of AMPA receptor function in cerebellar granule cells of ataxic mutant mouse stargazer. J Neurosci 19:6027-6036.

Hayes DM, Braud S, Hurtado DE, McCallum J, Standley S, Isaac JT, Roche KW (2003) Trafficking and surface expression of the glutamate receptor subunit, KA2. Biochem Biophys Res Commun 310:8-13.

Horning MS, Mayer ML (2004) Regulation of AMPA receptor gating by ligand binding core dimers. Neuron 41:379-388.

Köhler M, Kornau HC, Seeburg PH (1994) The organization of the gene for the functionally dominant alpha-amino-3-hydroxy-5-methylisoxazole-4propionic acid receptor subunit GluR-B. J Biol Chem 269:17367-17370.

Koike M, Tsukada S, Tsuzuki K, Kijima H, Ozawa S (2000) Regulation of kinetic properties of GluR2 AMPA receptor channels by alternative splicing. J Neurosci 20:2166-2174.

Kolleker A, Zhu JJ, Schupp BJ, Qin Y, Mack V, Borchardt T, Köhr G, Malinow R, Seeburg PH, Osten P (2003) Glutamatergic plasticity by synaptic delivery of GluR-B(long)-containing AMPA receptors. Neuron 40:1199-1212.

Kuismanen E, Saraste J (1989) Low temperature-induced transport blocks as tools to manipulate membrane traffic. Methods Cell Biol 32:257-274.

Letts VA, Felix R, Biddlecome GH, Arikkath J, Mahaffey CL, Valenzuela A, Bartlett II FS, Mori Y, Campbell KP, Frankel WN (1998) The mouse stargazer gene encodes a neuronal $\mathrm{Ca}^{2+}$-channel gamma subunit. Nat Genet 19:340-347.

Lomeli H, Mosbacher J, Melcher T, Höger T, Geiger JR, Kuner T, Monyer H, Higuchi M, Bach A, Seeburg PH (1994) Control of kinetic properties of AMPA receptor channels by nuclear RNA editing. Science 266:1709-1713.

Määttä J, Hallikas O, Welti S, Hilden P, Schröder J, Kuismanen E (2000) Limited caspase cleavage of human BAP31. FEBS Lett 484:202-206.

Mah SJ, Cornell E, Mitchell NA, Fleck MW (2005) Glutamate receptor trafficking: endoplasmic reticulum quality control involves ligand binding and receptor function. J Neurosci 25:2215-2225.

Malinow R, Malenka RC (2002) AMPA receptor trafficking and synaptic plasticity. Annu Rev Neurosci 25:103-126.

Mayer ML (2005) Glutamate receptor ion channels. Curr Opin Neurobiol 15:282-288.

Monyer H, Seeburg PH, Wisden W (1991) Glutamate-operated channels: developmentally early and mature forms arise by alternative splicing. Neuron 6:799-810.

Mosbacher J, Schoepfer R, Monyer H, Burnashev N, Seeburg PH, Ruppersberg JP (1994) A molecular determinant for submillisecond desensitization in glutamate receptors. Science 266:1059-1062.

Möykkynen T, Korpi ER, Lovinger DM (2003) Ethanol inhibits alphaamino-3-hydyroxy-5-methyl-4-isoxazolepropionic acid (AMPA) receptor function in central nervous system neurons by stabilizing desensitization. J Pharmacol Exp Ther 306:546-555.

Ng FW, Nguyen M, Kwan T, Branton PE, Nicholson DW, Cromlish JA, Shore GC (1997) p28 Bap31, a bcl-2/Bcl-XL- and procaspase-8-associated protein in the endoplasmic reticulum. J Cell Biol 139:327-338.

Nicoll RA, Tomita S, Bredt DS (2006) Auxiliary subunits assist AMPA-type glutamate receptors. Science 311:1253-1256.

Okabe S, Miwa A, Okado H (1999) Alternative splicing of the C-terminal domain regulates cell surface expression of the NMDA receptor NR1 subunit. J Neurosci 19:7781-7792.

Palmer CL, Cotton L, Henley JM (2005) The molecular pharmacology and cell biology of alpha-amino-3-hydroxy-5-methyl-4-isoxazolepropionic acid receptors. Pharmacol Rev 57:253-277.
Partin KM, Bowie D, Mayer ML (1995) Structural determinants of allosteric regulation in alternatively spliced AMPA receptors. Neuron 14:833-843.

Passafaro M, Piech V, Sheng M (2001) Subunit-specific temporal and spatial patterns of AMPA receptor exocytosis in hippocampal neurons. Nat Neurosci 4:917-926.

Pasternack A, Coleman SK, Jouppila A, Mottershead DG, Lindfors M, Pasternack M, Keinänen K (2002) Alpha-amino-3-hydroxy-5-methyl-4isoxazolepropionic acid (AMPA) receptor channels lacking the N-terminal domain. J Biol Chem 277:49662-49667.

Priel A, Kolleker A, Ayalon G, Gillor M, Osten P, Stern-Bach Y (2005) Stargazin reduces desensitization and slows deactivation of the AMPA-type glutamate receptors. J Neurosci 25:2682-2686.

Quirk JC, Nisenbaum ES (2003) Multiple molecular determinants for allosteric modulation of alternatively spliced AMPA receptors. J Neurosci 23:10953-10962.

Quirk JC, Siuda ER, Nisenbaum ES (2004) Molecular determinants responsible for differences in desensitization kinetics of AMPA receptor splice variants. J Neurosci 24:11416-11420.

Ren Z, Riley NJ, Garcia EP, Sanders JM, Swanson GT, Marshall J (2003) Multiple trafficking signals regulate kainate receptor KA2 subunit surface expression. J Neurosci 23:6608-6616.

Sheng M, Hyoung Lee S (2003) AMPA receptor trafficking and synaptic plasticity: major unanswered questions. Neurosci Res 46:127-134.

Shi S, Hayashi Y, Esteban JA, Malinow R (2001) Subunit-specific rules governing AMPA receptor trafficking to synapses in hippocampal pyramidal neurons. Cell 105:331-343.

Sommer B, Keinänen K, Verdoorn TA, Wisden W, Burnashev N, Herb A, Köhler M, Takagi T, Sakmann B, Seeburg PH (1990) Flip and flop: a cell-specific functional switch in glutamate-operated channels of the CNS. Science 249:1580-1585.

Sommer B, Köhler M, Sprengel R, Seeburg PH (1991) RNA editing in brain controls a determinant of ion flow in glutamate-gated channels. Cell 67:11-19.

Sun Y, Olson R, Horning M, Armstrong N, Mayer M, Gouaux E (2002) Mechanism of glutamate receptor desensitization. Nature 417:245-253.

Swanson GT, Kamboj SK, Cull-Candy SG (1997) Single-channel properties of recombinant AMPA receptors depend on RNA editing, splice variation, and subunit composition. J Neurosci 17:58-69.

Tang BL, Wang Y, Ong YS, Hong W (2005) COPII and exit from the endoplasmic reticulum. Biochim Biophys Acta 1744:293-303.

Tomita S, Chen L, Kawasaki Y, Petralia RS, Wenthold RJ, Nicoll RA, Bredt DS (2003) Functional studies and distribution define a family of transmembrane AMPA receptor regulatory proteins. J Cell Biol 161:805-816.

Tomita S, Adesnik H, Sekiguchi M, Zhang W, Wada K, Howe JR, Nicoll RA, Bredt DS (2005) Stargazin modulates AMPA receptor gating and trafficking by distinct domains. Nature 435:1052-1058.

Valluru L, Xu J, Zhu Y, Yan S, Contractor A, Swanson GT (2005) Ligand binding is a critical requirement for plasma membrane expression of heteromeric kainate receptors. J Biol Chem 280:6085-6093.

Vandenberghe W, Nicoll RA, Bredt DS (2005) Interaction with the unfolded protein response reveals a role for stargazin in biosynthetic AMPA receptor transport. J Neurosci 25:1095-1102.

Xia H, Hornby ZD, Malenka RC (2001) An ER retention signal explains differences in surface expression of NMDA and AMPA receptor subunits. Neuropharmacology 41:714-723.

Xia H, von Zastrow M, Malenka RC (2002) A novel anterograde trafficking signal present in the N-terminal extracellular domain of ionotropic glutamate receptors. J Biol Chem 277:47765-47769.

Zhu JJ, Esteban JA, Hayashi Y, Malinow R (2000) Postnatal synaptic potentiation: delivery of GluR4-containing AMPA receptors by spontaneous activity. Nat Neurosci 3:1098-1106. 